\title{
PENGARUH REWARD DAN PUNISHMENT TERHADAP MOTIVASI BELAJAR PENDIDIKAN AGAMA ISLAM SISWA DI SMP NEGERI 3 PADANGSIDIMPUAN
}

\author{
Rini Agustini \\ Dosen Univesitas Muhammadiyah Tapanuli Selatan \\ Email: riniagustini216@gmail.com
}

\begin{abstract}
The problem that is often faced by teachers when the learning process takes place is finding students who are not enthusiastic in attending the lesson. Teachers are always required to be able to motivate students, because in learning there is a need for motivation. The more precise the motivation given, the more successful the lesson will be for students. One of the Islamic education tools that can motivate students to learn is reward and punishment. So, the reward and punishment can be done by the teacher to increase student motivation so that they get good achievements. The problem is whether there is a significant effect of reward and punishment on the motivation to learn students' Islamic education simultaneously at Padangsidimpuan 3 Public Middle School? The purpose of this study was to determine whether there was a significant effect of reward and punishment on the learning motivation of students' Islamic Education simultaneously in Padangsidimpuan 3 Public Middle School. The results of this study there is a significant effect of reward on student learning motivation of 0.715 , its contribution is $51.1225 \%$, the remaining $48.8775 \%$ is determined by other variables. This gives a statement that the reward has a strong influence on student learning motivation. The magnitude of the effect of punishment on student learning motivation is 0.567 , its contribution is $32.1489 \%$, the remaining $67.85 \%$ is determined by other variables. This gives a statement that punishment has a strong enough influence on student learning motivation. The magnitude of the effect of reward and punishment is 0.734 , its contribution is $53.8756 \%$, the remaining $46.124 \%$ is determined by other variables. It provides information that reward and punishment simultaneously have a strong influence on student learning motivation.
\end{abstract}

Keywords: Reward, punishment, and learning motivation.

\section{PENDAHULUAN}

Konsep reward dan punishment merupakan pengukuran pendidikan bagi kualitas fungsional edukatif siswa yang berprestasi dan bermasalah. Hadiah, penghargaan, dan cenderamata adalah urgen diberikan kepada mereka yang berprestasi. Sebaliknya, hukuman sebagai vaksinasi dini dalam konteks pendidikan pun layak diberikan kepada mereka yang bermasalah. ${ }^{1}$

Pembelajaran efektif, bukan membuat murid pusing, akan tetapi bagaimana tujuan pembelajaran dapat tercapai dengan mudah dan menyenangkan. Motivasi sebagai gejala psikologi menjadi amat penting dalam pengembangan dan pembinaan potensi individu karena potensi motivasi ini menjadi satu kekuatan seseorang untuk melakukan sesuai dengan yang diinginkan serta tingkat kekuatannya untuk mencapai keinginan tersebut.

${ }^{1}$ A. Malik Fadjar, Holistika Pemikiran Pendidikan, (Jakarta: PT RajaGrafindo Persada, 2005), h. 201 
Motivasi belajar timbul karena dua faktor, yaitu faktor intrinsik berupa hasrat dan keinginan berhasil dan dorongan kebutuhan belajar, harapan akan cita-cita. Selanjutnya faktor ekstrinsiknya adalah adanya penghargaan, lingkungan belajar yang kondusif, dan kegiatan belajar yang menarik.2

Motivasi belajar timbul karena dua faktor, yaitu faktor intrinsik berupa hasrat dan keinginan berhasil dan dorongan kebutuhan belajar, harapan akan cita-cita. Selanjutnya faktor ekstrinsiknya adalah adanya penghargaan, lingkungan belajar yang kondusif, dan kegiatan belajar yang menarik. 3

Motivasi belajar timbul karena dua faktor, yaitu faktor intrinsik berupa hasrat dan keinginan berhasil dan dorongan kebutuhan belajar, harapan akan cita-cita. Selanjutnya faktor ekstrinsiknya adalah adanya penghargaan, lingkungan belajar yang kondusif, dan kegiatan belajar yang menarik.4

Motivasi belajar timbul karena dua faktor, yaitu faktor intrinsik berupa hasrat dan keinginan berhasil dan dorongan kebutuhan belajar, harapan akan cita-cita. Selanjutnya faktor ekstrinsiknya adalah adanya penghargaan, lingkungan belajar yang kondusif, dan kegiatan belajar yang menarik. 5

Reward dan punishment merupakan cara yang efektif dan strategis bila digunakan sesuai dengan prinsip-prinsip belajar untuk merangsang peserta didik agar lebih giat dalam pembelajaran dan untuk mengembangkan potensi peserta didik. Reward menurut Saodah Nasution, berarti: 1) imbalan; upah, 2) memberi upah.6 Selanjutnya punish berarti menghukum dan punishmet adalah hukuman.7 Ganjaran dan hukuman sebagai alat pendidikan yang cukup penting dalam memotivasi siswa agar lebih giat dalam belajar. Al-Ghazali berpendapat, bahwa jika anak melakukan perbuatan yang baik dan berakhlak terpuji, hendaknya ia dimuliakan dan dipuji. Jika mungkin, ia diberi hadiah yang baik. Dipuji dihadapan orang-orang penting dan berkedudukan, sebagai motivasi baginya. 8

Latar belakang masalah dalam penelitian ini dilandasi oleh empat landasan yaitu landasan filosofis, teologis, teoritis, dan faktual. Adapun landasan yang pertama adalah landasan filosofis yang terdapat dalam UU SISDIKNAS No. 20 Tahun 2003, bab II pasal 3 mengenai Tujuan Pendidikan Nasional yang bunyinya:

"Pendidikan nasional bertujuan mengembangkan kemampuan dan pembinaan watak serta peradaban bangsa yang bermartabat dalam rangka mencerdaskan kehidupan bangsa, bertujuan untuk berkembangnya potensi peserta didik agar menjadi manusia yang beriman dan bertakwa kepada Tuhan Yang Maha Esa, berilmu, cakap, kreatif, mandiri, dan menjadi warga negara yang demokratis serta bertanggung jawab”.9

${ }^{2}$ Hamzah B. Uno, Teori Motivasi \& Pengukuran: Analisis di Bidang Pendidikan, (Jakarta: Bumi Aksara, 2015), h. 23

${ }^{3}$ Ibid.

${ }^{4}$ Ibid.

${ }^{5}$ Ibid.

${ }^{6}$ Saodah, Nasution, Kamus Umum Lengkap Inggris-Indonesia, Indonesia-Inggris, (Jakarta: Mutiara Sumber Widya, 1989), h. 215-216

${ }^{7}$ Ibid., h. 199

${ }^{8}$ Fathiyyah Hasan Sulaiman, Alam Pikiran Al-Ghazali Mengenai Pendidikan dan Ilmu, Terj. A.A.Dahlan dkk,(Bandung: CV. Diponegoro, 1986), h. 80

${ }^{9}$ Undang-undang Sistem Pendidikan Nasional No. 20 Tahun 2003, (Jakarta: Sinar Grafika, 2009), h. 7 
Kedua, landasan teologis reward (ganjaran) dan punishment (hukuman). Ganjaran dan hukuman merupakan alat dalam pendidikan Islam. Ganjaran merupakan perlakuan menyenangkan yang diterima peserta didik dari pendidiknya sebagai buah dari prestasi dan perbuatan baik yang telah dicapai atau dilakukan oleh peserta didik.10 Sebaliknya, hukuman dalam istilah psikologi adalah cara yang digunakan pada waktu keadaan yang merugikan atau pengalaman yang tidak menyenangkan yang dilakukan oleh seseorang dengan sengaja menjatuhkan orang lain. Secara umum disepakati bahwa hukuman adalah ketidaknyamanan (suasana tidak menyenangkan) dan perlakuan yang buruk atau yang jelek. Berkaitan dengan konsep ganjaran dan hukuman terdapat dalam firman Allah SWT dalam Q.S. Al-Zalzalah7-8

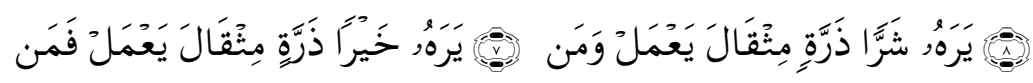

Artinya: "Barang siapa yang melakukan kebaikan seberat dzarrahpun, niscaya dia akan melihat (balasan) nya, dan barang siapa yang melakukan kejahatan seberat dzarrahpun, niscaya dia akan melihat balasannya”.11

Kata dzarrah ada yang memahaminya dalam arti semut yang kecil pada awal kehidupannya, atau kepala semut. Ada juga yang menyatakan dia adalah debu yang terlihat beterbangan dicelah cahaya matahari yang masuk melalui lubang dan jendela. Sebenarnya kata ini digunakan untuk menggambarkan sesuatu terkecil, sehingga apapun makna kebahasaannya, yang jelas adalah ayat ini menegaskan bahwa manusia akan melihat amal perbuatannya sekecil apapun amal itu.12

Ketiga, landasan teoritis. Adapun teori yang digunakan dalam penelitian ini adalah teori behavior dari Skinner tentang teori pembelajaran perilaku (operant conditioning).

Skinner, adalah salah seorang tokoh yang sangat berperan dalam teori pembelajaran perilaku yang telah mempelajari hubungan antara tingkah laku dan konsekuensinya mengemukakan bahwa belajar merupakan perubahan perilaku. Prinsip yang paling penting dari teori belajar perilaku adalah bahwa perilaku berubah sesuai dengan konsekuensi-konsekuensi langsung dari perilaku tersebut. Konsekuensi yang menyenangkan akan memperkuat perilaku, sedangkan konsekuensi-konsekuensi yang tidak menyenagkan akan memperlemah perilaku. Dengan kata lain konsekuensikonsekuensi yang menyenangkan akan meningkatkan frekuensi seseorang untuk melakukan perilaku yang serupa.

Konsekuensi yang menyenangkan disebut penguat (reinforcer), sedangkan konsekuensi yang tidak menyenangkan disebut hukuman (punisher). Penggunaan konsekuensi-konsekuensi yang menyenangkan dan yang tidak menyenangkan untuk mengubah perilaku sering disebut pengkondisian operan (operant conditioning). Dengan diberikannya penguatan dan hukuman itu, maka akan terjadi perubahan tingkah laku. Karena itu, memberikan konsekuensi penguatan atau hukuman yang sesegera mungkin akan lebih baik daripada diberikan dibelakangan dan akan memberikan pengaruh positif terhadap perilaku selanjutnya. Jadi pemberian konsekuensi sesegera mungkin dalam

\footnotetext{
${ }^{10}$ Dja’far Siddik, Konsep Dasar Ilmu Pendidikan Islam (Bandung: Citapustaka Media, 2006), hlm. 145.

${ }^{11}$ Departemen Agama RI, Al-Qur'an dan Terjemahannya, (Jakarta: Cahaya Intan Cemerlang, 2009), h. 599

${ }^{12}$ M. Quraish Shihab, Tafsir Al-Misbah: Pesan, Kesan dan Keserasian Al-Quran, (Jakarta: Lentera Hati, 2002), Volume 15, h. 455
} 
proses pembelajaran itu penting, supaya kesalahan yang sama tidak dilakukan lagi oleh para siswa.13

Keempat, landasan faktual. Berdasarkan pengamatan yang dilakukan peneliti di SMP Negeri 3 Padangsidimpuan, bahwa guru pendidikan agama Islam telah dapat meningkatkan motivasi para siswanya dengan memberikan reward kepada siswa yang berprestasi dan punishment kepada siswa yang melakukan perbuatan yang buruk yang dapat merugikan orang lain.

Adapun reward yang diberikan guru pendidikan agama Islam kepada siswa adalah berupa peringkat dan simbol, seperti ranking, centang tanda benar yang diberikan kepada peserta didik jika peserta didik berhasil mengerjakan tugas yang diberikan oleh guru. Selain itu, guru juga menyuruh peserta didik ke depan untuk menulis jawaban dari tugas yang bagus yang sudah dikerjakan. Berbentuk sentuhan, seperti menyalam siswa yang berprestasi, ini dilakukan pada saat anak mendapat ranking di sekolah. Hadiah, penguatan secara verbal seperti pujian, contohnya: "bagus, bagus sekali, benar, benar sekali” yang diberikan kepada semua peserta didik yang dapat menjawab pertanyaan atau soal-soal yang diberikan oleh guru. Sementara kalau berbentuk hadiah itu biasanya seperti buku tulis dan memberikan beasiswa kepada peserta didik yang berprestasi yang diserahkan di lapangan sekolah dengan mengumumkan nama-nama perserta didik yang berprestasi. Sedangkan punishment yang diberikan guru adalah menyuruh siswa duduk dibangku paling depan jika siswa tersebut membuat keributan ketika proses pembelajaran berlangsung, menyuruh anak menghapal surat-surat pendek jika anak tidak mengerjakan $\mathrm{PR}$, dan menulis surah-surah pendek tersebut.Sementara untuk siswa yang terlambat datang ke sekolah disuruh mengutip sampah sebelum masuk kelas.

Selanjutnya reward dan punishment yang diterapkan guru pendidikan agama Islam bertujuan untuk meningkatkan motivasi ekstrinsik siswa tetapi secara faktual bahwa motivasi belajar siswa masih rendah. Hal ini dapat dilihat dari kelakuan-kelakuan peserta didik ketika mengikuti proses pembelajaran. Seperti mengobrol dengan teman sebangku, duduknya menyender ke dinding tembok kelas kalau peserta didiknya duduk di samping dinding tembok, lesu, dan lain sebagainya. Jadi, di sini sudah terlihat jelas bahwa peserta didik kurang bersemangat ketika mengikuti proses pembelajaran sehingga nilai ulangan yang didapatkan oleh peserta didik berada di bawah KKM. Adapun KKM untuk mata pelajaran Pendidikan Agama Islam adalah 80. Untuk itu, agar motivasi pesera didik tidak menurun lagi, guru pendidikan agama Islam memberikan reward dan punishment dalam proses pembelajaran. Dengan demikian diharapkan motivasi peserta didik dalam proses pembelajaran bertambah.

Berdasarkan hal di atas, maka penulis ingin mengkaji hal tersebut, sehingga merumuskan judul: "Pengaruh Reward Dan Punishment Terhadap Motivasi Belajar Pendidikan Agama Islam Siswa Di SMP Negeri 3 Padangsidimpuan”.

\section{A. Landasan Teori}

\section{Motivasi Belajar}

\section{a. Pengertian Motivasi}

Motivasi satu kekuatan yang merupakan dorongan individu untuk melakukan sesuatu seperti yang diinginkan, atau dikehendakinya. Motivasi

\footnotetext{
${ }^{13}$ Trianto, Mendesain Model Pembelajaran Inovatif-Progresif: Konsep, Landasan, dan Implementasinya pada Kurikulum Tingkat Satuan Pendidikan (KTSP), (Jakarta: Kencana, 2012), h. $39-40$
} 
sebagai gejala psikologi menjadi amat penting dalam pengembangan dan pembinaan potensi individu karena potensi motivasi ini menjadi satu kekuatan seseorang untuk melakukan sesuai dengan yang diinginkan serta tingkat kekuatannya untuk mencapai keinginan tersebut. Dalam psikologi behaviorisme motif adalah suatu pernyataan jiwa yang kompleks di dalam suatu organisme yang mengarahkan tingkah laku atau perbuatan ke suatu tujuan atau perangsang. Motivasi pada eksistensinya sangat penting khususnya dalam pengembangan atau pengaktualisasian diri seorang individu. Menurut para ahli ada beberapa fungsi motif tersebut, yakni:

1) Motif adalah mendorong manusia untuk berbuat atau bertindak

2) Motif itu menentukan arah perbuatan manusia

3) Motif itu menyeleksi perbuatan manusia.

Dalam proses kerjanya maka motivasi itu mempunyai kerja sebagai berikut, yakni: menggerakkan, mengarahkan, dan menopang tingkah laku manusia. Jadi jelas bahwa motivasi merupakan satu potensi individu yang harus menjadi landasan bagi proses pembinaan dan pengembangan kepribadian. ${ }^{14}$ Dengan demikian dapat dipahami bahwa motivasi itu adalah mendorong seseorang untuk melakukan sesuatu yang dinginkannya dalam pengembangan kpribadiannya.

Motivasi adalah memberikan arah yang baik terhadap perilaku manusia. Dalam konteks pendidikan, motivasi belajar adalah yang memberikan arahan terhadap perilaku siswa dalam situasi akademis. Siswa yang belajar harus diberi motivasi untuk belajar dengan harapan, bahwa belajar akan memperoleh hadiah. Misalnya, siswa-siswa dapat mengharapkan bahwa informasi akan memenuhi keingintahuan mereka tentang suatu pokok bahasan, akan berguna bagi mereka, atau dapat menolong mereka untuk memperoleh angka yang lebih baik. ${ }^{15}$

Ada dua prinsip yang dapat digunakan untuk meninjau motivasi, ialah:

a. Motivasi dipandang sebagai suatu proses. Pengetahuan tentang proses ini akan membantu kita menjelaskan kelakukan yang kita amati dan untuk memperkirakan kelakuan-kelakuan lain pada seseorang;

b. Kita menentukan karakter dari proses ini dengan melihat petunjuk-petunjuk dari tingkah lakunya. Apakah petunjuk-petunjuk ini dapat dipercaya, dapat dilihat kegunaannya dalam memperkirakan dan menjelaskan tingkah laku lainnya. ${ }^{16}$

\section{b. Fungsi Motivasi dalam Belajar}

Dalam belajar sangat diperlukan adanya motivasi. "Motivation is an essential condition of learning”. Hasil belajar akan menjadi optimal, kalau ada ada motivasi. Makin tepat motivasi yang diberikan, akan makin berhasil pula pelajaran itu. Jadi motivsi akan senantiasa menentukan intensitas usaha belajar bagi para siswa. Perlu ditegaskan, bahwa motivasi bertalian dengan suatu tujuan.

${ }^{14}$ Chalidjah Hasan, Dimensi-dimensi Psikologi Pendidikan, (Surabaya: Al-Ikhlas, 1994), h. $42-43$

${ }^{15}$ Ratna Wilis Dahar, Teori-teori Belajar, (Jakarta: Erlangga, 1989), h. 141

${ }^{16}$ Oemar Hamalik, Proses Belajar Mengajar, (Jakarta: Bumi Aksara, 2004), Cet. ke-3, h. 
Sehubungan dengah hal tersebut ada tiga fungsi motivasi menurut Sardiman ${ }^{17}$, yaitu:

1) Mendorong manusia untuk berbuat, jadi sebagai penggerak atau motor yang melepaskan energi. Motivasi dalam hal ini merupakan motor penggerak dari setiap kegiatan yang akan dikerjakan.

2) Menentukan arah perbuatan, yakni kearah tujuan yang hendak dicapai. Dengan demikian motivasi dapat memberikan arah dan kegiatan yang harus dikerjakan sesuai dengan rumusan tujuannya.

3) Menyeleksi perbuatan, yakni yang menentukan perbuatan-perbuatan apa yang harus dikerjakan yang serasi guna mencapai tujuan, dengan menyisihkan perbuatan-perbuatan yang tidak bermanfaat bagi tujuan tersebut.

Dengan kata lain bahwa dengan adanya usaha yang tekun dan terutama didasari adanya motivasi, maka seseorang yang belajar itu akan dapat melahirkan prestasi yang baik. Intensitas motivasi seorang siswa akan sangat menentukan tingkat pencapaian prestasi belajarnya.

\section{c. Peran Guru Memotivasi Belajar}

Motivasi belajar adalah mendorong atau memberi semangat kepada siswa yang melakukan kegiatan belajar agar prestasinya lebih baik. ${ }^{18}$ Pada dasarnya bahwa motivasi merupakan kondisi psikologis yang mendorong seseorang untuk melakukan sesuatu. Dalam kegiatan belajar, motivasi dapat dikatakan sebagai keseluruhan daya penggerak di dalam diri murid yang menimbulkan, menjamin kelangsungan, dan memberiakan arah kegiatan belajar, sehingga diharapkan tujuan dapat tercapai. Dalam kegiatan belajar, motivasi sangat diperlukan, sebab seseorang yang tidak mempunyai motivasi dalam belajar, tidak akan mungkin melakukan aktivitas belajar. Motivasi ada dua, yaitu:

a. Motivasi Intrinsik. Jenis motivasi ini timbul dari dalam diri individu sendiri tanpa ada paksaan dorongan orang lain, tetapi atas dasar kemauan sendiri.

b. Motivasi Ekstrinsik. Jenis motivasi ini timbul sebagai sebagai akibat pengaruh dari luar individu, apakah karena adanya ajakan, suruhan, atau paksaan dari orang lain sehingga dengan keadaan demikian murid mau melakukan sesuatu atau belajar.

Bagi murid yang selalu memerhatikan materi pelajaran yang diberikan bukanlah masalah bagi guru. Karena di dalam diri murid tersebut ada motivasi, yaitu motivasi intrinsik. Murid yang demikian biasanya dengan kesadaran sendiri memerhatikan penjelasan guru. Rasa ingin tahunya lebih banyak terhadap materi pelajaran yang diberikan. Berbagai gangguan yang ada di sekitarnya, kurang dapat memengaruhinya agar memecahkan perhatiannya. Lain halnya bagi murid yang tidak ada motivasi di dalam dirinya, maka motivasi ekstrinsik yang merupakan dorongan dari luar dirinya mutlak diperlukan. Di sini tugas guru adalah membangkitkan motivasi peserta didik sehingga ia mau melakukan belajar.

\section{Reward}

\section{a. Pengertian Reward}

\footnotetext{
${ }^{17}$ Sardiman, Interaksi dan motivasi Belajar Mengajar: Pedoman Bagi Guru dan Calon Guru,(Jakarta: PT RajaGrafindo Persada, 1996), Cet. ke-6, h. 84-85

${ }^{18}$ Nursyamsi, Psikologi Pendidikan, (Padang: Baitul Hikmah, 2003), h. 115
} 
Reward dalam Kamus Inggris Indonesia menurut John M. Echols dan Hassan Shadily, adalah: a) Ganjaran, hadiah, menawarkan hadiah, hadiah atas usahanya, ganjaran sebagai seorang guru. b) Upah, pahala, mendapat upah/pahala/ganjaran. c) Diberi hadiah untuk usaha-usahanya. d) Memberikan penghargaan. e) Menghadiahi, menghadiahkan. f) Membalas. ${ }^{19}$ Ganjaran dalam Kamus Istilah Pendidikan dan Umum adalah hadiah, pembalas jasa, alat pendidikan yang diberikan kepada murid-murid yang telah dapat mencapai prestasi baik. ${ }^{20}$

Mengacu kepada Duke dan Canady yang dikutip oleh Syafaruddin, bahwa Reward (imbalan) dibagi kepada tiga bagian, yaitu: ${ }^{21}$

a. Extrinsic reward (reward buatan), yaitu adanya imbalan bergantung pada kedudukan seseorang secara langsung. Muncul dari prestise dan kekuasaan sesuai peranannya sehingga berbeda atas yang lain.

b. Instrinsic reward (imbalan murni) adalah bersifat subjektif dan alamiah, karena itu bersifat pribadi.

c. Ancitarry reward (imbalan tambahan), yaitu imbalan bersifat objektif simultan dan subjektif mencakup aspek pekerjaan yang dinilai oleh kelompok tertentu.

\section{b. Hal-hal yang Harus Dipertimbangkan dalam Memberikan Hadiah}

Beberapa hal yang perlu dijadikan bahan pertimbangan dalam memberikan hadiah berupa benda menurut Suharsismi Arikunto, antara lain; ${ }^{22}$

1. Hadiah tersebut harus benar-benar berhubungan dengan prestasi yang dicapai.

2. Hadiah berupa benda sebaiknya disesuaikan dengan kebutuhan siswa yang menerima.

3. Hadiah yang berupa benda sebaiknya tidak perlu terlalu mahal.

Edward Lee Thorndike yang dikutip oleh Netti Hartati dengan teori law of effect, mengemukakan bahwa perilaku yang menimbulkan kesenangan akan mengakibatkan perilaku itu terulang kembali, sebaliknya tingkah laku yang tidak mendatangkan kesenangan akan menjadikan pelakunya meninggalkan perilaku tersebut. ${ }^{23}$ Memberikan hukuman dan ganjaran kepada seseorang sangat erat kaitannya dengan psikologi. Kesalahan yang sama belum tentu harus memberikan hukuman yang sama bagi orang yang berbeda, karena boleh jadi bagi yang satu hukuman itu sudah sangat berat baginya dan sudah cukup menghentikannya dari mengulangi kesalahan yang serupa, tapi sangat memungkinkan bagi orang yang lain bahwa hukuman itu tidak cukup untuk menghentikannya dari kesalahan-kesalahannya, karena dia sudah terbiasa menghadapi hal yang sama bagi lingkungannya. Untuk itu perlu

\footnotetext{
${ }^{19}$ John M. Echols dan Hassan Shadily, Kamus Inggris Indonesia: An English-Indonesia Dictionary, (Jakarta: PT Gramedia Pustaka Utama, 2003), Cet. ke-XXV, h. 485

${ }^{20}$ Sastrapradja, Kamus Istilah Pendidikan dan Umum, (Surabaya: Usaha Nasional, 1981), h. 169

${ }^{21}$ Syafaruddin, Efektivitas Kebijakan Pendidikan: Konsep, Strategi, dan Aplikasi Kebijakan Menuju Organisasi Sekolah Efektif, (Jakarta: Rineka Cipta, 2008), h. 142

${ }^{22}$ Ibid., h. 165

${ }^{23}$ Netty Hartati, dkk, Islam dan Psikologi, (Jakarta: RajaGrafindo Persada, 2004), h. 57
} 
diberikan hukuman yang tepat yang dapat menghentikannya atau orang lain dari kesalahan-kesalahan selanjutnya. ${ }^{24}$

\section{Punishment}

\section{a. Pengertian Punishment}

Punishment menurut John M. Echols dan Hassan Shadily dalam Kamus Inggris Indonesia: An English-Indonesian Dictionary, berarti hukuman, siksaan, dan perlakuan yang amat kasar, sedangkan punish adalah menghukum, menyiksa. ${ }^{25}$

Punishment dalam Kamus Psikologi adalah tindakan memberikan stimulasi yang tidak menyenangkan sebagai hukuman karena melakukan sesuatu yang tidak tepat atau karena gagal melakukan sesuatu yang merupakan tujuan; setiap bentuk stimulasi yang diberikan kepada seseorang yang dirasakannya sebagai tidak menyenangkan dan yang biasanya dicoba untuk dihindarinya. ${ }^{26}$

Hukuman dalam Kamus Istilah Pendidikan dan Umum adalah suatu perbuatan dimana seseorang secara sadar dan sengaja menjatuhkan nestapa kepada orang lain dengan tujuan memperbaiki atau melindungi dirinya dari kelemahan jasmani dan rohani sehingga terhindar dari segala macam pelanggaran. ${ }^{27}$

Hukuman ini dianjurkan oleh Rouseau dan menurut Spencer yang dikutip oleh Suwarno, hukuman ini mempunyai kebaikan-kebaikan sebagai berikut: ${ }^{28}$

1. Anak belajar mengetahui akibat yang wajar dari perbuatannya.

2. Anak merasa hukuman ini sebagai hukuman adil.

3. Karena itu hukuman ini tidak menyakitkan hati anak.

4. Hingga hubungan antara guru dan anak tetap baik.

Menurut Jeanne Ellis Ormrod peneliti dan pendidik telah mengidentifikasi beberapa bentuk hukuman yang ringan yang bisa efektif mengurangi perilaku yang bermasalah dikelas: ${ }^{29}$

a. Teguran verbal (scolding)

Meski beberapa siswa tampak berusaha keras mendapatkan omelan dari guru karena mendapat perhatian dari situ, kebanyakan siswa, khususnya bila mereka sesekali diomeli, menganggap teguran verbal tidak menyenangkan dan menusuk hati. Umumnya, teguran lebih efektif ketika disampaikan secara langsung, singkat, dan tidak emosional. Teguran juga memiliki efek yang bagus ketika disampaikan secara halus dan tidak diketahui siswa-siswa lain. Teguran sedapat mungkin disampaikan secara privat. Ketika mengomeli seorang siswa di depan teman-teman kelas, beberapa siswa yang diomeli mungkin menikmati perhatian dari teman-teman sebayanya, sementara yang lain bisa merasa sangat malu.

b. Konsekuensi logis (logical consequences)

${ }^{24}$ Ibid.

${ }^{25}$ John M. Echols dan Hassan Shadily, op.cit., h. 456

${ }^{26}$ Kartini Kartono dan Dali Gulo, op.cit., h. 394-395

${ }^{27}$ Sastrapradja, op.cit., h. 201

${ }^{28}$ Ibid., h. 116

${ }^{29}$ Jeanne Ellis Ormrod, Psikologi Pendidikan: Membantu Siswa Tumbuh dan Berkembang, Terj. Wahyu Indianti, dkk, (Jakarta: Erlangga, 2008), h. 455-457 
Suatu akibat yang terjadi secara alamiah atau logis setelah siswa berperilaku tidak sesuai disebut konsekuensi logis. Dalam hal ini, konsekuensi logis merupakan hukuman yang cocok dengan tindak kejahatan. Sebagai contoh ketika siswa menghancurkan barang temannya, konsekuensi yang masuk akal adalah siswa tersebut menggantinya atau membyarnya untuk membeli yang baru. Apabila siswa berbicara terlalu banyak sehingga lupa mengerjakan tugas-tugasnya, konsekuensi logisnya adalah mereka dipisahkan. Bila seorang siswa secara sengaja membuat kekacauan dikategorikan.

\section{B. Pembahasan dan Hasil Penelitian}

\section{Pengujian Hipotesis}

Untuk melakukan pengujian hipotesis yang diajukan dalam penelitian ini, sebagaimana yang diolah menggunakan rumus regresi ganda. Dalam kajian teoritis yang dilakukan pada bagian terdahulu, penulis mempunyai dugaan yang kuat bahwa "Terdapat Pengaruh Reward dan Punishment Terhadap Motivasi Belajar Pendidikan Agama Islam Siswa di SMP Negeri 3 Padangsidimpuan”.

Oleh karena itu, dilakukan pengujian dalam penelitian ini merupakan hipotesis alternatif, artinya sejauhmana “Terdapat Pengaruh Reward dan Punishment Terhadap Motivasi Belajar Pendidikan Agama Islam Siswa di SMP Negeri 3 Padangsidimpuan”.

Hipotesis tersebut dapat diterima apabila " $r$ tabel" dengan taraf signifikansi 5\% atau tingkat kepercayaan 95\% dengan derajat kebebasan $\mathrm{dk}=\mathrm{N}$ $\mathrm{nr}$ atau 90-2= 88 lebih kecil dari "r hitung". Begitu juga sebaliknya apabila indeks korelasi "r hitung” lebih kecil dari "r tabel” maka hipotesis ditolak.

Untuk menguji hipotesis, maka nilai $\mathrm{r}$ hitung $\left(\mathrm{r}_{\mathrm{xy}}\right)$ dikonsultasikan kepada $\mathrm{r}$ tabel $\left(\mathrm{r}_{\mathrm{t}}\right)$, yaitu N-nr $=90-2=88$. Pada tabel " $\mathrm{r}$ " Product Moment ditemukan nilai $r$ tabel $\left(r_{t}\right)$ untuk df $=88$ pada tingkat kepercayaan 5\% sebesar 0,213. Dengan demikian hipotesis yang berbunyi "terdapat hubunganyang signifikan antara reward dan punishmant terhadap motivasi belajar pendidikan agama Islam siswa di SMP Negeri 3 Padangsidimpuan"diterima karena $r$ hitung $\left(\mathrm{r}_{\mathrm{xy}}=0,734>\right.$ $\left.\mathrm{r}_{\mathrm{t}}=0,213\right)$. Artinya semakin banyakreward dan punishment yang diterapkan oleh guru maka motivasi belajar siswa di SMP Negeri 3 Padangsidimpuan akan semakin tinggi.

Dari uji anova atau $F_{\text {tes }}$, ternyata didapat $F_{\text {hitung }}$ adalah 50,908 dengan tingkat signifikan 0,000 karena probabilitas $(0,000)$ jauh lebih kecil dari 0,05 sehingga model regresi dapat dipakai untuk memprediksi motivasi belajar siswa. Dari tabel 4.19 menggambarkan bahwa persamaan regresi sebagai berikut:

$\ddot{\mathrm{Y}}=\mathrm{a}+b_{1} x_{1}+b_{2} x_{2}=74,846+0,691 x_{1}+0,249 x_{2}$

Dimana:

$x_{1}=$ reward

$X_{2}=$ punishment

$\mathrm{Y}=$ motivasi belajar

Konstanta sebesar 0,691menyatakan bahwa jika tidak ada kenaikan nilai variabel reward (X1) dan punishment (X2), maka motivasi belajar pendidikan agama Islam siswa (Y) adalah 0,587. Koefisien regresi sebesar 0,249 menyatakan bahwa setiap penambahan (karena tanda + ) satu skor atau nilai kemampuan akan memberikan peningkatan skor sebesar 0,249. 
Terlihat pada kolom sig (signifikansi) pada tabel 4.18 terdapat nilai 0,0001 atau probabilitas jauh di bawah 0,05 karena nilai $F_{\text {hitung }}>$ nilai $F_{\text {tabel }} \quad$ 50,908 $>3,96$, maka Ho ditolak artinya koefisien regresi signifikan atau reward dan punishment berpengaruh secara signifikan terhadap motivasi belajar pendidikan agama Islam siswa di SMP Negeri 3 Padangsidimpuan.

\section{KESIMPULAN}

Berdasarkan uraian pada beberapa bab terdahulu sebelumnya, maka penulis dapat mengambil kesimpulan sebagai berikut:

a. Reward dan punishment secara simultan berpengaruh secara signifikan terhadap motivasi belajar siswa. Besarnya pengaruh variabel reward dan punishment secara simultan terhadap motivasi belajar siswa adalah 0,734 sedangkan kontribusi variabel X1 dan X2 terhadap Y sebesar 53,8756\% kemudian sisanya 46,1244\% ditentukan oleh variabel lain. Informasi ini memberikan keterangan bahwa variabel reward dan punishment secara simultan memberikan pengaruh kuat terhadap motivasi belajar siswa.

Data empiris telah membuktikan bahwa reward dan punishment dapat memotivasi belajar pendidikan agama Islam siswa di SMP Negeri 3 Padangsidimpuan. Berdasarkan penelitian di lapangan, peneliti mengemukakan beberapa saran diantaranya:

a. Bagi para siswa di SMP Negeri 3 Padangsidimpuan

1) Hendaknya siswa terus termotivasi untuk lebih giat dan semangat dalam belajar dan pembelajaran agar tercapainya tujuan pendidikan terutama pendidikan Islam.

2) Siswa diharapkan untuk lebih aktif lagi dalam mengikuti proses pembelajaran terutama dalam mata pelajaran Pendidikan Agama Islam agar kriteria ketuntasan minimal yang ditetapkan dapat tercapai.

b. Bagi Guru Bidang Studi Pendidikan Agama Islam

1) Hendaknya guru pendidikan agama Islam lebih memahami bagaimana cara membangkitkan motivasi belajar siswa.

2) Hendaknya guru pendidikan agama Islam lebih mendalami bagaimana cara memberikan reward dan punishment yang tepat guna untuk meningkatkan motivasi siswa dalam belajar.

c. Kepada Kepala Sekolah di SMP Negeri 3 Padangsidimpuan

1) Hendaknya kepala sekolah di SMP Negeri 3 Padangsidimpuanselalu membekali dan menambah pengetahuan para guru tentang cara menerapkan reward dan punishment dengan yang baik.

2) Hendaknya kepala sekolah di SMP Negeri 3 Padangsidimpuan selalu memberikan arahan, nasihat, dan motivasi kepada para siswa agar selalu giat dan aktif dalam belajar dan pembelajaran.

d. Bagi Peneliti

1) Bagi peneliti ada kemungkinan kelemahan yang terjadi dalam pelaksanaan penelitian ini. Oleh karena itu,masih perlu diadakan penelitian lebih lanjut dengan memperbesar objek penelitian.

2) Bagi peneliti yang ingin meneliti lebih lanjut lagi pada masalah dalam penelitian ini supaya memperhatikan variabel lain yang mungkin turut berpengaruh terhadap motivasi belajar siswa.

\section{DAFTAR PUSTAKA}


Al-Muaddib : Jurnal Ilmu-Ilmu Sosial \& Keislaman http://jurnal.um-tapsel.ac.id/index.php/al-muaddib/ issn online : 2549-0427 | issn cetak : 2528-2492 Volume 1 Nomor 2 ( Januari-Juni) 2019

Chalidjah Hasan, Dimensi-dimensi Psikologi Pendidikan, Surabaya: Al-Ikhlas, 1994.

Departemen Agama RI, Al-Qur'an dan Terjemahannya, Jakarta: Cahaya Intan Cemerlang, 2009.

Dja’far Siddik, Konsep Dasar Ilmu Pendidikan Islam Bandung: Citapustaka Media, 2006.

Fathiyyah Hasan Sulaiman, Alam Pikiran Al-Ghazali Mengenai Pendidikan dan Ilmu, Terj. A.A.Dahlan dkk, Bandung: CV. Diponegoro, 1986.

Hamzah B. Uno, Teori Motivasi \& Pengukuran: Analisis di Bidang Pendidikan, Jakarta: Bumi Aksara, 2015.

Jeanne Ellis Ormrod, Psikologi Pendidikan: Membantu Siswa Tumbuh dan Berkembang, Terj. Wahyu Indianti, dkk, Jakarta: Erlangga, 2008.

John M. Echols dan Hassan Shadily, Kamus Inggris Indonesia: An English-Indonesia Dictionary, Jakarta: PT Gramedia Pustaka Utama, 2003, Cet. ke-XXV

M. Quraish Shihab, Tafsir Al-Misbah: Pesan, Kesan dan Keserasian Al-Quran, Jakarta: Lentera Hati, 2002, Volume 15.

Malik Fadjar, Holistika Pemikiran Pendidikan, Jakarta: PT RajaGrafindo Persada, 2005.

Netty Hartati, dkk, Islam dan Psikologi, Jakarta: RajaGrafindo Persada, 2004.

Nursyamsi, Psikologi Pendidikan, Padang: Baitul Hikmah, 2003.

Oemar Hamalik, Proses Belajar Mengajar, Jakarta: Bumi Aksara, 2004, Cet. ke-3

Ratna Wilis Dahar, Teori-teori Belajar, Jakarta: Erlangga, 1989.

Saodah Nasution, Kamus Umum Lengkap Inggris-Indonesia, Indonesia-Inggris, Jakarta: Mutiara Sumber Widya, 1989.

Sardiman, Interaksi dan motivasi Belajar Mengajar: Pedoman Bagi Guru dan Calon Guru,Jakarta: PT RajaGrafindo Persada, 1996, Cet. ke-6.

Sastrapradja, Kamus Istilah Pendidikan dan Umum, Surabaya: Usaha Nasional, 1981.

Syafaruddin, Efektivitas Kebijakan Pendidikan: Konsep, Strategi, dan Aplikasi Kebijakan Menuju Organisasi Sekolah Efektif, Jakarta: Rineka Cipta, 2008.

Trianto, Mendesain Model Pembelajaran Inovatif-Progresif: Konsep, Landasan, dan Implementasinya pada Kurikulum Tingkat Satuan Pendidikan (KTSP), Jakarta: Kencana, 2012. 
Al-Muaddib : Jurnal Ilmu-Ilmu Sosial \& Keislaman http://jurnal.um-tapsel.ac.id/index.php/al-muaddib/ issn online : 2549-0427 | issn cetak : 2528-2492 Volume 1 Nomor 2 ( Januari-Juni) 2019

Undang-undang Sistem Pendidikan Nasional No. 20 Tahun 2003, Jakarta: Sinar Grafika, 2009. 